\title{
PELATIHAN PENGASUHAN ANAK DENGAN GANGGUAN PEMUSATAN PERHATIAN DISERTAI HIPERAKTIVITAS (GPPH)
}

\section{TRAINING OF PARENTING A CHILD WITH ATTENTION DEFICIT HIPERACTIVITY DISORDER (ADHD)}

\author{
Mefisya Nuzullia \\ Juke R. Siregar \\ Afra Hafni Noer \\ Fakultas Psikologi Universitas Padjadjaran Bandung \\ Email:mefisya@gmail.com
}

\begin{abstract}
Parents who have children with ADHD often make improper parenting on children's behavior. As a result, the symptoms of $A D H D$ continue and develop into comorbid. This parent training program was aimed to improve the understanding of parents how to handle children with ADHD. The participants of this study were three mothers with children aged 7-9 years who have ADHD. The research design was quasi experiment with one group pre test - post test design, using the observational guide and questionnaire to determine the behavior and management of children with ADHD. Hypothesis was tested with Wilcoxon signed-rank test. The results showed that parenting training can improve mother's understanding in dealing with the behavior of ADHD children.
\end{abstract}

Keywords : ADHD, understanding ADHD, parenting training.

\begin{abstract}
ABSTRAK
Orang tua yang memiliki anak Gangguan Pemusatan Perhatian disertai Hiperaktivitas (GPPH) sering melakukan pola pengasuhan yang tidak tepat terhadap perilaku anak. Akibatnya, gejala GPPH berlanjut dan berkembang menjadi komorbid. Program pelatihan pengasuhan ini bertujuan untuk meningkatkan pemahaman orang tua akan penanganan anak-anak dengan GPPH. Para peserta penelitian ini adalah tiga ibu-ibu dengan anak-anak berusia 7 - 9 tahun yang memiliki gangguan GPPH. Desain penelitian ini adalah eksperimen semu dengan satu kelompok pre test - post test design. Peneliti menggunakan panduan observasi dan kuesioner untuk mengetahui dan manajemen perilaku GPPH. Hipotesis diuji dengan Wilcoxon signed-rank test. Hasil penelitian menunjukkan bahwa pelatihan pengasuhan anak GPPH dapat meningkatkan pemahaman ibu dalam mengatasi anak dengan perilaku GPPH.
\end{abstract}

Kata kunci : GPPH, pemahaman GPPH, pelatihan pengasuhan. 
Saat anak mulai mengikuti pendidikan formal, tuntutan bagi anak menjadi lebih besar dibandingkan ketika mereka masih di prasekolah. Usia bermain pada anak mulai beralih menjadi usia sekolah dan belajar. Pada saat ini mulai banyak muncul keluhan-keluhan kesulitan pada anak terutama yang terkait dengan kesulitan belajar, seperti kesulitan membaca, menulis, berhitung, duduk diam di kelas, dan berkonsentrasi. Ada beberapa anak yang sering kali melamun di kelas, mengobrol, mengganggu siswa lain di kelas, dan tidak bisa diam. Mereka selalu terganggu oleh setiap hal kecil dan tidak pernah mampu belajar dari kesalahan-kesalahan mereka. Anak-anak ini mengabaikan peraturan, meskipun sudah dihukum berulang kali. Anak juga cenderung bertindak tanpa berpikir sehingga mengakibatkan banyak kecelakaan dan teguran. Akibatnya, anak tidak dapat menangkap pelajaran secara utuh dan nilai-nilai mata pelajarannya buruk (Wiguna, 2009).

Jika keluhan-keluhan di atas menetap dalam jangka waktu yang cukup lama dan konsisten dalam berbagai setting, maka perlu ditelaah lebih lanjut. Berdasarkan Diagnostic Statistic Manual IV-TR (DSM IV-TR), keluhan di atas merupakan gambaran dari perilaku yang menunjukkan adanya Gangguan Pemusatan Perhatian disertai Hiperaktivitas yang biasa dikenal sebagai GPPH. GPPH adalah keadaan neurologis perilaku dengan gejala-gejala yang meliputi kurangnya perhatian (inattentiveness), perilaku impulsif (impulsivity), dan aktivitas yang berlebihan (overactivity) yang tidak sesuai dengan ciri-ciri tahapan perkembangan anak. Kelainan ini dapat mengganggu perkembangan anak dalam hal kognitif, perilaku, sosialisasi, maupun komunikasi (Sattler, 2002; Kaplan \& Saddock, 2005; Barkley, 2006).

Prevalensi GPPH sekitar 3-5\% pada anak usia sekolah (Wenar \& Kerig, 2000). Pendiri/pimpinan klinik perkembangan anak dan kesulitan belajar "Smart Kid" di Jakarta, Dr. dr. Dwidjo Saputro Sp. KJ, menjelaskan bahwa berdasarkan penelitian di Indonesia, di setiap kelas di Sekolah Dasar diperkirakan 25\% anak mengalami masalah dengan atensinya dan umumnya diikuti oleh perilaku tidak bisa diam atau hiperaktif. Pada umumnya, anak usia SD yang didiagnosis banyak mengalami masalah tersebut berusia antara 7 sampai 10 tahun (Wiguna, 2009). Dalam konteks yang serupa, Barkley (Flick, 1998) mengungkapkan bahwa ketika anak GPPH berusia 7-10 tahun, masalah dalam ketiga karakteristik utama berlanjut dan ditambah dengan berbagai kesulitan perilaku lainnya.

Pada saat di sekolah, anak GPPH sulit menyelesaikan pekerjaan, cepat bosan terhadap pelajaran atau sulit mendengarkan pelajaran yang diberikan guru di kelas sehingga di kelas sering mengobrol atau sering melamun. Rentang perhatian yang pendek membuat anak 
ingin cepat selesai bila mengerjakan tugastugas sekolah sehingga dalam mengerjakan soal sering salah, tetapi bukan karena tidak bisa melainkan karena tidak teliti. Akibatnya dalam pelajaran sekolah akan didapatkan nilai mata pelajaran tertentu sangat tinggi tetapi pelajaran lainnya sangat jelek. Nilai pelajaran naik turun drastis. Di rumah, anak tampak tidak bisa belajar lama. Bila belajar, mereka harus dalam keadaan tenang atau biasanya saat tengah malam. Sebaliknya anak biasanya bisa bertahan lama pada hal yang disukai, seperti menonton televisi, baca komik atau main game. Anak dengan gangguan konsentrasi tertentu tidak terganggu bila menghadapi hal yang disukai, tetapi akan sangat bosan terhadap hal yang tidak disukai (Judarwanto, 2008).

Selain itu hasil penelitian Anastopoulus (Odom, 1996) menjelaskan bahwa lebih dari 50\% anak GPPH juga mengalami kesulitan dalam relasi sosial dengan orang lain. Dibandingkan dengan anak umumnya, anak GPPH biasanya lebih mudah cemas dan kecil hati. Hal ini berkaitan dengan rendahnya toleransi terhadap frustrasi sehingga bila mengalami kekecewaan, anak gampang emosional. Anak GPPH juga cenderung keras kepala dan mudah marah bila keinginannya tidak segera dipenuhi. Hambatan-hambatan tersebut membuat anak menjadi kurang mampu menyesuaikan diri dengan lingkungannya. Akibatnya, ada kecenderungan peningkatan terjadinya konflik dengan lingkungan.
Berdasarkan penjelasan di atas, dapat diterima adanya pandangan bahwa anak GPPH merupakan tantangan yang luar biasa bagi banyak pihak. Sayangnya gangguan ini kurang dikenal dengan baik oleh orangtua, guru, dan masyarakat. Menurut Martin (2008), lingkungan mengenal anak dengan GPPH sebagai anak yang memiliki sikap "melawan", malas, kurang konsentrasi, atau anak "nakal" yang tidak mau diam. Tidak peduli betapa keras usaha orangtua untuk mengarahkan, anak GPPH terus saja melamun, tidak mampu untuk duduk tenang, mengganggu, temper tantrum, mengabaikan tanggung jawabnya, dan tidak mampu menjalin hubungan pertemanan atau menjaga persahabatan. Kondisi hubungan relasi sosial yang buruk ini menimbulkan kekhawatiran pada orangtua. Catatan-catatan dari guru dan keluhan-keluhan dari para orangtua lain mengenai anak GPPH menambah peningkatan kondisi stres pada orangtua. Bahkan bisa mengakibatkan persepsi orangtua terhadap dirinya sendiri menjadi buruk dan orang tua merasa tidak mampu berperan sebagai orangtua yang baik.

Hal ini menarik bagi peneliti mengingat secara teoritis dijelaskan bahwa kurangnya pengetahuan orangtua mengenai keterbatasan anak membuat pola perilaku orangtua terhadap anak menjadi tidak tepat. Orang tua menjadi banyak mengontrol, kurang responsif terhadap pertanyaan anak, sering memerintah, tidak konsisten dan 
memberikan hukuman sebagai metode pendisiplinan, serta hanya sedikit memberikan perhatian terhadap perilaku yang positif. Akibatnya gejala GPPH terus berlanjut dan berkembangnya berbagai komorbid (Gomez \& Sanson, dalam Odom, 1996).

Cukup banyak program pelatihan pengasuhan yang telah ditawarkan sebagai intervensi untuk menangani anak dengan GPPH dan kebanyakan menggunakan teknik modifikasi perilaku. Salah satu ahli yang secara spesifik merancang program khusus behavioral parent training adalah Barkley pada tahun 1987 dan telah mengalami sedikit modifikasi pada tahun 1997 (Barkley, 2006). Program ini diperuntukkan bagi orangtua untuk anak usia 4-12 tahun dan fokus pada proses sosial di dalam keluarga untuk mengembangkan atau mempertahankan kepatuhan anak GPPH. Tujuan utama dari program Barkley ini ada dua. Tujuan pertama adalah meletakkan pondasi pengetahuan yang akan mendukung dan meningkatkan keterampilan spesifik yang diajarkan. Tujuan kedua adalah untuk memonitor beragam kemampuan yang telah diperoleh orangtua dari keterampilan manajemen anak, yang telah disesuaikan dengan kebutuhan anak-anak dengan GPPH.

Berdasarkan dua tujuan tersebut, langkah awal untuk memulai program ini adalah orangtua harus diberi serangkaian pengetahuan konseptual yang praktis mengenai GPPH. Kemudian program ini juga ditujukan untuk meningkatkan pemahaman berkenaan dengan prinsip manajemen perilaku, agar dapat meningkatkan pemeliharaan keterampilan sepanjang waktu dan dalam berbagai setting. Berdasarkan pengetahuan tersebut, selanjutnya program ini dirancang untuk mengajarkan orang tua sejumlah strategi untuk berhadapan dengan permasalahan perilaku anak secara efektif (Barkley, 2006). Hal ini membuat peneliti tertarik untuk menggunakan prinsip-prinsip pendekatan behavioral parent training dari Barkley sebagai landasan perancangan program pelatihan pengasuhan dalam penelitian ini.

Saat ini beberapa penelitian di lingkungan Magister Profesi Psikologi mengenai intervensi GPP/GPPH yang sudah dikembangkan kebanyakan untuk meningkatkan kemampuan anak GPPH atau meningkatkan kemampuan anak GPPH melalui ibu. Sejauh pengetahuan peneliti, belum ada intervensi atau penelitian yang terkait dengan pelatihan pengasuhan untuk meningkatkan pengetahuan ibu dalam menangani permasalahan tingkah laku anak GPPH. Berdasarkan hal tersebut, peneliti tertarik untuk menguji efektivitas program pelatihan pengasuhan untuk meningkatkan pemahaman ibu dalam menangani permasalahan tingkah laku anak usia 7-9 tahun yang mengalami Gangguan Pemusatan Perhatian disertai 
Hiperaktivitas (GPPH). Hipotesis dalam penelitian ini adalah program pelatihan pengasuhan anak dengan GPPH dapat meningkatkan pemahaman ibu dalam menangani permasalahan tingkah laku anaknya.

\section{METODE PENELITIAN}

\section{Subjek Penelitian}

Subjek penelitian adalah tiga orang ibu yang berada di tempat terapi $X$ di Surakarta. Gambaran karakteristik peserta pelatihan adalah sebagai berikut:

1. Ibu yang memiliki anak usia 7-9 tahun yang telah didiagnosis gangguan pemusatan perhatian disertai hiperaktivitas murni (tanpa menunjukkan gangguan perkembangan, kerusakan intelektual, atau gangguan kesehatan lainnya) oleh Psikiater.

2. Belum pernah mengikuti pelatihan manajemen perilaku anak GPPH.

3. Latar belakang pendidikan minimal setingkat SMA.

4. Bersedia mengikuti seluruh rang-kaian program pelatihan dan evaluasinya, yang dibuktikan dengan pengisian informed consent

\section{Desain Penelitian}

Penelitian ini menggunakan desain penelitian quasi eksperimen dengan one group pretest and postest design.

\section{Pengukuran}

Alat ukur yang digunakan dalam penelitian ini ada dua, yaitu (1) kuesioner pengetahuan GPPH dan Manajemen Perilaku Anak GPPH, dan (2) panduan observasi demonstrasi pemahaman ibu dalam menangani permasalahan tingkah laku anak GPPH.

Evaluasi hasil uji coba pelatihan pengasuhan ini terdiri dari dua hal. Evaluasi yang pertama adalah evaluasi mengenai peningkatan pemahaman ibu dalam menangani permasalahan tingkah laku anak GPPH dengan menggunakan pendekatan prates-pascates.

Evaluasi yang kedua mengenai hasil pelaksanaan uji coba program yang datanya diperoleh dari proses selama pelatihan dan evaluasi reaksi peserta terhadap pelaksanaan program pelatihan pengasuhan ini. Hasil evaluasi ini digunakan untuk mengetahui dampak keberhasilan dari program pelatihan yang sudah dilaksanakan dan sebagai landasan dalam melakukan revisi program pelatihan pengasuhan terhadap hal-hal yang dirasakan masih kurang dan perlu diperbaiki guna pengembangan di kemudian hari.

\section{Prosedur Intervensi}

Pemilihan sampel dalam penelitian ini dilakukan dengan metode purposive sampling, yaitu pemilihan sekelompok subjek didasarkan pada karakteristik penelitian dalam unit populasi. Peneliti mencari di tempat terapi $\mathrm{X}$ semua ibu dari anak yang telah didiagnosis GPPH oleh profesional, dan saat ini berusia 7-9 tahun. Kemudian peneliti mengirimkan 
surat pengantar dari tempat terapi dan dari peneliti, kepada ibu yang memenuhi karakteristik penelitian untuk meminta kesediaannya sebagai subjek penelitian. Di samping itu, peneliti juga melakukan kontak melalui telepon kepada semua calon subjek dengan tujuan yang sama seperti pengiriman surat. Diharapkan dengan melakukan kontak langsung melalui telepon peneliti dapat dijelaskan secara mendalam mengenai tujuan dan sasaran dari penelitian. Para ibu yang berminat diminta mengisi informed consent sebagai komitmen untuk mengikuti seluruh rangkaian kegiatan penelitian ini dari tahap asesmen kebutuhan hingga evaluasi program pelatihan yang telah dilaksanakan.

Pelatihan pengasuhan ini diberikan kepada ibu selama 4 kali pertemuan dan terdiri dari 7 sesi, yaitu (1) sesi memberi gambaran mengenai GPPH, (2) sesi memahami hubungan orangtua-anak, (3) sesi perhatian positif, (4) sesi menggunakan konsekuensi untuk membentuk target perilaku yang baik, (5) sesi penggunaan time out, (6) sesi mengelola perilaku anak di area publik, (7) sesi memahami isu seputar permasalahan di sekolah. Hasil dari pelaksanaan uji coba program ini digunakan untuk merevisi rancangan program pelatihan pengasuhan.

\section{Teknik Analisis Data}

Data penelitian ini dianalisis dengan menggunakan Wilcoxon signed-rank test dengan menggunakan program SPSS 17.0 for Windows.

\section{HASIL PENELITIAN}

Hasil pelatihan dimaksudkan untuk menguji hipotesis utama penelitian yaitu "Uji coba program pelatihan pengasuhan yang telah disusun dapat meningkatkan pemahaman ibu dalam menangani permasalahan tingkah laku anak usia 7-9 tahun yang mengalami Gangguan Pemusatan Perhatian disertai Hiperaktivitas (GPPH)". Untuk menjawab hipotesis tersebut, dalam operasionalnya perhitungan statistik dilakukan dengan menggunakan dua hipotesis minor, yaitu:

1. Hipotesis 1: Pelatihan pengasuhan berpengaruh terhadap pengetahuan ibu mengenai GPPH dan manajemen perilaku anak GPPH usia 7-9 tahun Hipotesis statistiknya adalah:

$\mathrm{H}_{0}$ : Tidak terdapat peningkatan pengetahuan ibu mengenai GPPH dan manajemen perilaku anak GPPH usia 7-9 tahun setelah pelatihan pengasuhan diberikan

$M_{\mathrm{e}}$ post-test $\leq \mathrm{M}_{\mathrm{e}}$ pre-test

$\mathrm{H}_{1}$ : Terdapat peningkatan pengetahuan ibu mengenai GPPH dan manajemen perilaku anak GPPH usia 7-9 tahun setelah pelatihan pengasuhan diberkan $M_{\mathrm{e}}$ post-test $>M_{\mathrm{e}}$ pre-test

2. Hipotesis 2: Pelatihan pengasuhan berpengaruh terhadap demonstrasi pemahaman ibu dalam menangani 
permasalahan tingkah laku anak GPPH usia 7-9 tahun

Hipotesis statistiknya adalah:

$\mathrm{H}_{0}$ : Tidak terdapat peningkatan demonstrasi pemahaman ibu dalam menangani permasalahan tingkah laku anak GPPH usia 7-9 tahun setelah pelatihan pengasuhan diberikan $M_{\mathrm{e}}$ post-test $\leq M_{\mathrm{e}}$ pre-test
$\mathrm{H}_{1}$ : Terdapat peningkatan demonstrasi pemahaman ibu dalam menangani permasalahan tingkah laku anak GPPH usia 7 - 9 tahun setelah pelatihan pengasuhan diberikan.

$M_{e}$ post-test $>M_{e}$ pre-test

Dengan menggunakan program SPSS 17.0 for Windows, pada output hasil pengujian atas kedua hipotesis diperoleh nilai seperti yang tertera pada table 1 .

Tabel 1. Hasil Uji Hipotesis

\begin{tabular}{llllll}
\hline Dimensi & Nilai Z & Keterangan & Nilai T & Keterangan & Kesimpulan \\
\hline $\begin{array}{l}\text { Pengetahuan } \\
\text { ibu }\end{array}$ & -1.970 & Z output $>$ Z tabel & 0.0245 & Nilai T $<0.05$ & H0 ditolak \\
\hline $\begin{array}{l}\text { Demonstrasi } \\
\text { pemahaman } \\
\text { ibu }\end{array}$ & -2.023 & Z output $>$ Z tabel & 0.0215 & Nilai T $<0.05$ & H0 ditolak \\
\hline
\end{tabular}

Berdasarkan tabel 1 simpulan yang diperoleh dari hasil uji statistik adalah sebagai berikut:

1. Terdapat peningkatan pengetahuan ibu mengenai gangguan pemusatan perhatian disertai hiperaktivitas $(\mathrm{GPPH})$ dan manajemen perilaku anak gangguan pemusatan perhatian disertai hiperaktivitas (GPPH) usia 7-9 tahun setelah pelatihan pengasuhan diberikan.

2. Terdapat peningkatan demonstrasi pemahaman ibu dalam menangani permasalahan tingkah laku anak GPPH usia 7-9 tahun setelah pelatihan pengasuhan diberikan.

\section{PEMBAHASAN}

Pelatihan pengasuhan adalah program yang sistematis dan terencana untuk para ibu yang memiliki anak dengan $\mathrm{GPPH}$, yang berisikan materi tentang cara menangani permasalahan tingkah laku anak GPPH berdasarkan prinsip-prinsip parent training dari Barkley (2006). Program pelatihan pengasuhan ini terdiri dari tujuh sesi dan dilakukan dalam format kelompok agar memungkinkan setiap peserta belajar dari keluarga lainnya dan saling mendukung satu sama lain. Proses belajar dalam penelitian ini ditinjau melalui proses perhatian, proses pengingatan, dan proses reproduksi 
motorik, sebagaimana prinsip social learning yang dikemukakan Bandura (1986). Hal ini meliputi presentasi yang bersifat mendidik mengenai materi, menggunakan tugas yang spesifik, serta bermain peran dan umpan balik.

Dalam proses perhatian, hal yang penting diperhatikan adalah suasana belajar yang menarik dan penyampaian yang sesuai dengan minat psembelajar. Berdasarkan pengamatan peneliti pada saat pelatihan, proses pemberian pengetahuan dalam suasana semi informal dan jumlah peserta pelatihan yang hanya tiga orang, terbukti memberi kesempatan yang lebih besar untuk berinteraksi dengan trainer dalam bentuk sharing dan tanya jawab. Bahkan saat tanya jawab ada subjek yang berupaya menyelaraskan pemahaman mengenai GPPH dengan mengungkapkan contoh nyata dari perilaku yang dimunculkan anaknya. Subjek tersebut terus bertanya secara berkelanjutan jika jawaban yang diberikan oleh trainer dirasa belum memuaskan, sehingga seperti mengarah pada konsultasi pribadi.

Meskipun demikian, cara subjek tersebut bertanya membuat peserta lain tertarik untuk mengemukakan pengetahuan atau pendapat mereka. Melalui suasana ini, tahap retensional dapat dipenuhi karena pembelajar berkesempatan memantapkan kembali konsep-konsep pengetahuan yang telah dipelajari sehingga timbul insight bagi subjek dan peserta lainnya. Hal ini didukung oleh kualifikasi trainer yang psikolog sekaligus terapis anak berkebutuhan khusus dan juga memiliki anak balita yang didiagnosis sebagai $\mathrm{GPPH}$, sehingga proses pembelajaran lebih efektif. Trainer juga dapat berempati dalam memberikan pemahaman berdasarkan kasus serta sudut pandang khas dari tiap peserta.

Sasaran pada tahap reproduksi motorik adalah sejauh mana peserta mampu mengujicobakan hal-hal yang telah dipelajari melalui bermain peran bersama anak. Berdasarkan pengamatan, umumnya subjek mengalami kesulitan mengendalikan perilaku anak pada sesi role play penerapan time out. Anak selalu berusaha meninggalkan lokasi time out sehingga para subjek harus mengeluarkan energi yang banyak untuk memastikan bahwa anak berada di lokasi time out sampai waktunya habis. Proses umpan balik dilakukan oleh trainer dan peserta lainnya. Semua subjek dapat menerima ketika dilakukan umpan balik dan terjalin kontak mata aktif saat mendengarkan penjelasan trainer ataupun saat umpan balik dari sesama peserta. Menurut Bandura (1986), hasil belajar akan lebih efektif manakala pembelajar diberi kesempatan untuk memperoleh dan melakukan umpan balik. Keaktifan berpartisipasi dan keterbukaan menerima perbedaan juga merupakan faktor penting yang akan mempengaruhi cepat lambatnya proses transformasi konsep atau pengetahuan peserta. 
Pelatihan ini berlangsung dalam empat kali pertemuan dengan alokasi waktu 2-5 jam setiap pertemuan. Dengan waktu pelatihan yang cukup singkat, tampaknya para subjek sudah memperlihatkan perubahan pemahaman dalam menangani permasalahan tingkah laku anak GPPH usia 7-9 tahun. Hal ini didukung oleh kesediaan subjek untuk mengikuti kegiatan secara menyeluruh, sikap yang terbuka dalam menceritakan pengalaman dan perasaannya selama mengikuti proses pelatihan dan selama mengerjakan tugas rumah, serta selalu berusaha melaksanakan tugas rumah yang diberikan. Dari data evaluasi peserta terhadap proses pelatihan, seluruh peserta berpendapat bahwa pelatihan ini memenuhi kebutuhan peserta dan menambah pengetahuan mengenai cara menangani perilaku anak GPPH. Bahkan dua orang subjek menyarankan agar pelatihan ini dilakukan secara berkala sehingga subjek mengetahui apakah penerapan program dapat bermanfaat.

Kedua hasil pengujian hipotesis menunjukkan ke arah peningkatan, sehingga secara keseluruhan dapat disimpulkan bahwa pelatihan pengasuhan berpengaruh terhadap peningkatan pemahaman ibu dalam menangani permasalahan tingkah laku anak usia 7-9 tahun yang mengalami gangguan pemusatan perhatian disertai hiperaktivitas (GPPH) untuk ketiga subjek uji coba di Surakarta.

\section{PENUTUP}

\section{Simpulan}

Berdasarkan hasil penelitian yang telah dilakukan, maka dapat disimpulkan bahwa pelaksanaan uji coba program pelatihan pengasuhan terbukti berpengaruh terhadap peningkatan pemahaman ibu dalam menangani permasalahan tingkah laku anak usia 7-9 tahun yang mengalami Gangguan Pemusatan Perhatian disertai Hiperaktivitas (GPPH). Hal ini dapat diketahui dari analisis kuantitatif yang menyebutkan bahwa terdapat perbedaan skor pengetahuan dan demonstrasi pemahaman ibu dalam menangani permasalahan tingkah laku anak GPPH antara sebelum dan setelah pelatihan pengasuhan diberikan.

\section{Saran}

Penelitian selanjutnya sebaiknya juga melibatkan ayah dari anak yang mengalami GPPH dalam pelatihan ini agar terjadi konsistensi perlakuan terhadap anak di rumah. Dalam penelitian selanjutnya perlu dilakukan monitoring setelah tiga bulan pelaksanaan program pelatihan pengasuhan. Hal ini dimaksudkan untuk memastikan bahwa pengetahuan yang telah diperoleh dapat diterapkan secara efektif.

\section{DAFTAR PUSTAKA}

Bandura, A. (1986). Social Foundations of Thought and Action: A Social Cognitive Theory. New Jersey: Prentice-Hall. 
Barkley, R A. (2006). Attention Deficit Hyperactivity Disorder. A Handbook for Diagnosis and Treatment. $3^{\text {nd }}$ Edition. New York : The Guilford Press.

Barkley, R A. (2005). Taking Charge of ADHD: The Complete, Authoritative Guide for Pareents. Revised Edition. New York : The Guilford Press.

Flick, G. L. (1998). ADD/ADHD BehaviorChange Resouce kit: Ready-to-Use Strategies \& Activities for Helping Children with Attention Deficit Disorder. New York: The center for Applied Research Education.

Judarwanto, W. (2008). Gangguan Konsentrasi Anak Sekolah. Diunduh pada 12 Februari 2009. http://anakhiperaktif.blogspot.com/2008/04/ gangguan-konsentrasi-normalkah. html.

Kaplan \& Saddock. (2005). Comprehensive Text Book of Psychiatry. Philadelphia: Lippincott Williams \& Willkins.
Martin, G.L. (2008). Terapi untuk Anak ADHD. Terjemahan Tanto Hendy. Jakarta: PT. Bhuana Ilmu Komputer.

Odom, S.E. (1996). Effects of an Educational Intervention on Mothers of male Children With ADHD. Journal of Community Health Nursing. 13(4), 207-220.

Sattler J.M. (2002). Assesment of Children Behavioral and Clinical Application $4^{\text {th }}$ edition. San Dieogo : Jerome M. Satler, Publisher, Inc.

Wenar, C \& Kerig, P. (2000). Developmental Psychopathology From Infancy Through Adolescence. New York: McGraw Hill.

Wiguna, T. (2009). Deteksi \& Penangangan ADHD. Tabloid Nakita. No.535/ Th.XI/29 Juni - 5 Juli 2009. 